\title{
Medications that cause weight gain and alternatives in Canada: a narrative review
}

This article was published in the following Dove Press journal:

Diabetes, Metabolic Syndrome and Obesity:Targets and Therapy

\author{
Sean Wharton ${ }^{1,2}$ \\ Lilian Raiber' \\ Kristin J Serodio' \\ Jasmine Lee' \\ Rebecca AG Christensen' \\ 'The Wharton Medical Clinic, Toronto, \\ Canada; ${ }^{2}$ School of Kinesiology and \\ Health Science, York University, \\ Toronto, Canada
}

Correspondence: Rebecca AG

Christensen

The Wharton Medical Clinic, 402 - 658

Danforth Avenue, Toronto, Ontario M4J

5B9, Canada

Tel +l 4164533206

Fax $+|4| 646|4| 57$

Email wharton@whartonmedicalclinic. com
Background: The cause of the obesity epidemic is multifactorial, but may, in part, be related to medication-induced weight gain. While clinicians may strive to do their best to select pharmacotherapy(ies) that has the least negative impact on weight, the literature regarding the weight effects of medication is often limited and devoid of alternative therapies.

Results: Antipsychotics, antidepressants, antihyperglycemics, antihypertensives and corticosteroids all contain medications that were associated with significant weight gain. However, there are several medication alternatives within the majority of these classes associated with weight neutral or even weight loss effects. Further, while not all of the classes of medication examined in this review have weight-favorable alternatives, there exist many other tools to mitigate weight gain associated with medication use, such as changes in dosing, medication delivery or the use of adjunctive therapies.

Conclusion: Medication-induced weight gain can be frustrating for both the patient and the clinician. As the use of pharmaceuticals continues to increase, it is pertinent for clinicians to consider the weight effects of medications prior to prescribing or in the course of treatment. In the case where it is not feasible to make changes to medication, adjunctive therapies should be considered.

Keywords: weight gain, weight loss, weight neutral, adverse effects of medications, obesity, adjunctive therapy

\section{Introduction}

Worldwide, rates of obesity continue to rise, resulting in concurrent increases in metabolic disorders, such as type 2 diabetes and hypertension, which often require pharmacotherapy. This poses a major public health concern. Interestingly, close to $50 \%$ of North Americans will have taken a medication for a therapeutic purpose in the last 30 days. ${ }^{1,2}$ While pharmacotherapy is meant to be used for improving medical conditions, medications can be associated with a wide variety of adverse effects, including weight gain. ${ }^{1,3}$ This has tremendous consequences as excess weight is associated with worse health outcomes which can result in medication nonadherence in patients. Given these potentially poor outcomes combined with the global obesity crisis, it is important that clinicians consider the weight effects of medications.

There are several clinical guidelines that categorize medications as those that promote weight loss, weight gain or have weight neutral effects. However, inconsistencies exist when defining the weight effects of medication. Further, existing weight estimates are sparse, which makes it challenging for clinicians to recommend medications while 
considering the weight effects. This can result in weightrelated side effects of prescription medications being overlooked. Lastly, recently, some reviews have been published which examine the weight effect of medication. ${ }^{4,5}$ However, similar to clinical guidelines, they are either devoid of or only provide estimates for some of the medications discussed. Thus, this paper will provide a comprehensive overview of the medications associated with weight change and suggest pharmaceutical substitutions to promote a more favorable body weight response. Medication classes were selected based on their use in prevalent medical conditions that are complications or comorbidities of obesity.

\section{Classes of medications}

\section{Antipsychotics and mood stabilizers}

Psychopathologies are tightly linked with weight changes. ${ }^{6-9}$ Patients with mental health disorders are two to three times more likely to develop obesity than the general population. ${ }^{10}$ A review examining psychiatric medication effect on weight suggests that over the course of treatment, $\sim 70 \%$ of patients will experience some weight gain. ${ }^{6}$ A list of commonly used antipsychotics and their weight effects can be found in Table 1.

Medications for schizophrenia are known to result in significant weight gain. Clozapine- and olanzapine-treated patients can gain on average 4.5-16.2 ${ }^{11,13}$ and 3.6-10.2 $\mathrm{kg},{ }^{5,13-16}$ respectively. Nonetheless, there is considerable variability in the proportion of individuals that will experience

Table I Treatment-emergent weight changes associated with antipsychotics and mood stabilizers

\begin{tabular}{|c|c|}
\hline Drug name & Weight effect \\
\hline Aripiprazole ${ }^{15,20,29}$ & $-{ }^{\mathrm{a}}$ \\
\hline Carbamazepine $33,34,37,6$ & $--^{\mathrm{a}}$ \\
\hline Chlorpromazine ${ }^{18-20}$ & ++ \\
\hline Clozapine ${ }^{1 /-13}$ & $++^{\mathrm{a}}$ \\
\hline Haloperidol $20,23,24$ & $++^{\mathrm{a}}$ \\
\hline Iloperidone ${ }^{20,24,26}$ & $t^{\mathrm{a}}$ \\
\hline Lamotrigine $^{32,34,36, b}$ & $--^{\mathrm{a}}$ \\
\hline Lithium $^{30-33}$ & ++ \\
\hline Lurasidone $e^{20,26,28}$ & Neutral \\
\hline Olanzapine $e^{5,13-16}$ & $++^{\mathrm{a}}$ \\
\hline Paliperidone ${ }^{20,26,27}$ & $+\&-^{\mathrm{a}}$ \\
\hline Quetiapine ${ }^{20-22}$ & $++\&-$ \\
\hline Risperidone $^{13,20,24}$ & $t^{\mathrm{a}}$ \\
\hline Sertindole ${ }^{13,20,25}$ & $t^{\mathrm{a}}$ \\
\hline Valproic acid ${ }^{34-36, b}$ & $++^{\mathrm{a}}$ \\
\hline Ziprasidone ${ }^{13,16,20}$ & $-^{\mathrm{a}}$ \\
\hline
\end{tabular}

Notes: $+=>1 \mathrm{~kg}$. Neutral= $=1 \mathrm{~kg} .-=<-1 \mathrm{~kg}$. Additional + or - refers to $>3 \mathrm{~kg}$ weight change. ${ }^{a}$ Articles cited included $\geq \mathrm{l}$ weight neutral estimate(s). ${ }^{\mathrm{b}}$ Anticonvulsant and mood stabilizer. weight gain. Studies report that, on average, $29 \%-89 \% \%^{11,12}$ of patients receiving clozapine will gain some weight and $8 \%-37 \%$ of patients taking olanzapine will gain $\geq 7 \%$ of their body weight. ${ }^{15,17}$

Aside from clozapine and olanzapine, commonly prescribed medications for schizophrenia such as chlorpromazine $\left(0.6-15.9 \mathrm{~kg}^{18,20}\right)$, quetiapine $\left(-1.5\right.$ to $\left.+4.1 \mathrm{~kg}^{20,22}\right)$, haloperidol $\left(-0.1\right.$ to $\left.+4.0 \mathrm{~kg}^{20,23,24}\right)$, sertindole $(0.5-2.9$ $\left.\mathrm{kg}^{13,20,25}\right)$, iloperidone $\left(0.6-2.5 \mathrm{~kg}^{20,24,26}\right)$ and risperidone $\left(0.4-2.1 \mathrm{~kg}^{13,20,24}\right)$ are also reported to elicit significant weight gain. Conversely, the use of paliperidone $(-1.3$ to $\left.+1.9 \mathrm{~kg}^{20,26,27}\right)$, lurasidone $\left(0.1-0.9 \mathrm{~kg}^{20,26,28}\right)$, ziprasidone $\left(-1.1\right.$ to $\left.0.1 \mathrm{~kg}^{13,16,20}\right)$ and aripiprazole $\left(-1.4\right.$ to $\left.+0.2 \mathrm{~kg}^{15,20,29}\right)$ is associated with the least amount of weight gain among medications for schizophrenia, and thus, may be a more weight-favorable alternative.

Lithium is commonly prescribed for the treatment of bipolar disorder and has been associated with lesser, yet relevant weight gain (1.1-9.9 $\mathrm{kg}^{30,33}$ ). Additionally, valproic acid, a second-line treatment option for bipolar disorder, is also associated with significant gain in weight $\left(0.7-6.9 \mathrm{~kg}^{34,36}\right)$, albeit slightly lesser than reported with lithium. Conversely, lamotrigine $\left(-4.2\right.$ to $\left.+0.6 \mathrm{~kg}^{32,34,36}\right)$ and carbamazepine $(-3.1$ to $\left.+0.4 \mathrm{~kg}^{33,34,37}\right)$, mood stabilizers used in the treatment of epilepsy and bipolar disorder, are associated with weight neutral to weight loss properties and may be used in lieu of lithium or valproic acid as a more favorable weight alternative medication.

\section{Antidepressants}

Antidepressants consistently have a lower weight gain potential when compared to antipsychotics. However, antidepressants may carry a greater weight gain burden globally as they are prescribed more frequently than antipsychotics. ${ }^{38}$ There are five classes of antidepressants - tricyclic antidepressants (TCAs), monoamine oxidase inhibitors (MAOIs), selective serotonin reuptake inhibitors (SSRIs), serotonin-norepinephrine reuptake inhibitors and atypicals. Information on the weight effects of the five classes of antidepressants can be found in Table 2 .

TCAs have been prescribed since the 1950s and are reported to elicit the greatest weight gain among antidepressants. Amitriptyline (0.4-7.3 $\mathrm{kg}^{5,39,42}$ ) and nortriptyline $\left(0.3-4.1 \mathrm{~kg}^{39,40,42}\right)$ appear to be associated with the greatest amount of weight gain for these types of antidepressants. Other TCAs, such as desipramine $\left(-0.9\right.$ to $\left.+2.0 \mathrm{~kg}^{40,41,43}\right)$, imipramine $\left(+0.6-1.8 \mathrm{~kg}^{39,44,45}\right)$ and doxepin $\left(0.0-2.7 \mathrm{~kg}^{46,49}\right)$ are associated with more weight neutral effects. Lastly, 
Table 2 Treatment-emergent weight changes associated with antidepressants

\begin{tabular}{|c|c|}
\hline Drug name & Weight effect \\
\hline \multicolumn{2}{|l|}{ Atypical } \\
\hline $\begin{array}{l}\text { Bupropion (norepinephrine-dopamine reuptake } \\
\text { inhibitor) })^{5,42,47,51,66}\end{array}$ & $--^{\mathrm{a}}$ \\
\hline $\begin{array}{l}\text { Mirtazapine (noradrenergic and specific } \\
\text { serotonergic) }{ }^{5,42,71,72}\end{array}$ & $t^{\mathrm{a}}$ \\
\hline \multicolumn{2}{|l|}{ Monoamine oxidase inhibitors } \\
\hline Isocarboxazid 57,58 & $--^{\mathrm{a}}$ \\
\hline Phenelzine ${ }^{45,49,54,55}$ & $++^{\mathrm{a}}$ \\
\hline Tranylcypromine ${ }^{45,49,56}$ & $++^{\mathrm{a}}$ \\
\hline \multicolumn{2}{|l|}{ Selective serotonin reuptake inhibitor } \\
\hline Citalopram ${ }^{42,59-61}$ & $+t^{\mathrm{a}}$ \\
\hline Escitalopram ${ }^{42,60,64}$ & $t^{\mathrm{a}}$ \\
\hline Fluoxetine $e^{5,41-43,48,50,61}$ & $-^{\mathrm{a}}$ \\
\hline Fluvoxamine $^{61-63}$ & $+\&--^{a}$ \\
\hline Paroxetine $e^{42,61,65}$ & $+^{\mathrm{a}}$ \\
\hline Sertraline $e^{42,61,66,67}$ & $--^{\mathrm{a}}$ \\
\hline \multicolumn{2}{|l|}{ Serotonin-norepinephrine reuptake inhibitor } \\
\hline Desvenlafaxine ${ }^{68-70}$ & $+\&-^{\mathrm{a}}$ \\
\hline Duloxetine $\mathrm{e}^{42,64,65}$ & $t^{\mathrm{a}}$ \\
\hline Venlafaxine ${ }^{42,52,71,72}$ & $+\&-a$ \\
\hline \multicolumn{2}{|l|}{ Tricyclic antidepressant } \\
\hline Amitriptyline $\mathrm{e}^{5,39-42}$ & $++^{\mathrm{a}}$ \\
\hline Desipramine $^{40,41,43}$ & $t^{\mathrm{a}}$ \\
\hline Doxepin ${ }^{46-49}$ & $t^{\mathrm{a}}$ \\
\hline Imipramine ${ }^{39,44,45}$ & $t^{\mathrm{a}}$ \\
\hline Nortriptyline ${ }^{39,40,42}$ & $+t^{\mathrm{a}}$ \\
\hline Trazodone $\mathrm{e}^{50-52}$ & $-^{\mathrm{a}}$ \\
\hline
\end{tabular}

Notes: $+=>\mid \mathrm{kg}$. Neutral $= \pm$ | kg. $-=<-\mid \mathrm{kg}$. Additional + or - refers to $\geq 3 \mathrm{~kg}$ weight change. ${ }^{a}$ Articles cited included $\geq \mathrm{I}$ weight neutral estimate(s).

trazodone $\left(-1.2\right.$ to $\left.+0.9 \mathrm{~kg}^{50,52}\right)$ may have the most favorable weight profiles of all TCAs as a few studies have observed small amounts of weight loss with its use.

Studies consistently report that of the MAOIs, phenelzine elicits the greatest amount of weight gain. ${ }^{53}$ While several studies compare the use of phenelzine with other classes of antidepressants, there are only a few studies which adequately report on weight. Some studies ${ }^{45,54}$ report weight outcomes as no significant change with no weight estimate provided, while other studies examine weight gain as a side effect of phenelzine, but only report mean changes in the subpopulation experiencing these side effects, or based on a threshold. For example, one study observed a mean weight gain of 9.1 $\mathrm{kg}$ in 6 of 14 patients taking phenelzine ${ }^{55}$ and another reported a $6.8 \mathrm{~kg}$ weight gain in 11 of 141 patients. ${ }^{49}$ Conversely, tranylcypromine appears to have a more favorable weight change profile and is associated with lesser to no weight changes $\left(0.0-4.1 \mathrm{~kg}^{45,49,56}\right)$ in users. Additionally, isocarboxazid is reported to cause minor weight gain and even weight loss $\left(-2.6\right.$ to $\left.+0.8 \mathrm{~kg}^{57,58}\right)$, and may be used as a more favorable weight alternative when the use of MAOIs is indicated.

Citalopram $\left(-0.1\right.$ to $\left.+7.1 \mathrm{~kg}^{42,59,61}\right)$ is associated with the greatest amount of weight gain and fluvoxamine $(-3.5$ to +1.7 $\mathrm{kg}^{61,63}$ ) with the greatest amount of weight loss for SSRIs. However, in contrast to TCAs and MAOIs, other commonly prescribed SSRIs appear to be relatively weight neutral. Escitalopram $\left(-0.1\right.$ to $\left.+1.83 \mathrm{~kg}^{42,60,64}\right)$, paroxetine $(+0.1$ to 1.7 $\left.\mathrm{kg}^{42,61,65}\right)$, sertraline $\left(-1.6\right.$ to $\left.+1.0 \mathrm{~kg}^{42,61,66,67}\right)$ and fluoxetine $\left(-1.3\right.$ to $\left.+0.5 \mathrm{~kg}^{5,41,43,48,50,61}\right)$ are all associated with weight changes of around $\pm 2.0 \mathrm{~kg}$. Thus, weight neutral SSRIs such as fluoxetine or sertraline or those that have a trend toward weight loss, such as fluvoxamine, may be used as an alternative to citalopram. Comparatively, serotonin-norepinephrine reuptake inhibitors are often weight neutral and include agents such as duloxetine $\left(-0.5\right.$ to $\left.+1.1 \mathrm{~kg}^{42,64,65}\right)$, desvenlafaxine $\left(-1.3\right.$ to $\left.+1.3 \mathrm{~kg}^{68,70}\right)$ and venlafaxine $\left(-1.4\right.$ to $\left.+1.2 \mathrm{~kg}^{42,52,71,72}\right)$.

Atypical antidepressants are newer medications with distinct mechanisms from other classes of antidepressants. Mirtazapine is a used atypical antidepressant which is associated with a mean weight gain of $0.4-2.4 \mathrm{~kg},{ }^{5,42,71,72}$ while bupropion is associated with mean losses of 0.4 to $2.4 \mathrm{~kg}^{5,42,47,51,66}$ and is commonly used as a substitute for some SSRIs. ${ }^{18,19}$ Further, owing to the weight loss attributed to bupropion, it has been combined with naltrexone and approved as a weight management medication (Contrave ${ }^{\circledR}$; Valeant, Bridgewater Township, New Jersey, USA). Additional information on Contrave can be found in the "Considerations for pharmaceutical treatment" section.

\section{Antihyperglycemics}

There is a high prevalence of comorbid obesity and diabetes, with over $80 \%$ of patients who have type 2 diabetes also having obesity. Metformin is a first-line treatment option for type 2 diabetes $^{73}$ and is associated with favorable weight outcomes. Weight loss is reported as a known side effect of this medication, ${ }^{74}$ with average decreases of $1.0-2.9 \mathrm{~kg}^{5,75,78}$ (Table 3).

Alternative treatment options for patients with type 2 diabetes include thiazolidinediones. These medications carry a lower risk of hypoglycemia than other antihyperglycemic medications as they lower the blood sugar by making the body more sensitive to insulin rather than by increasing the production. However, thiazolidinediones are associated with the most weight gain of antihyperglycemics, second only to insulin. Pioglitazone and rosiglitazone are associated with gains in weight of $2-3.9^{5,79,81}$ and $1.2-5.3 \mathrm{~kg},{ }^{78,82,83}$ respectively. 
Table 3 Treatment-emergent weight changes associated with antihyperglycemics

\begin{tabular}{|c|c|}
\hline Drug name & Weight effect \\
\hline \multicolumn{2}{|c|}{ a-glucosidase inhibitors } \\
\hline Acarbose $\mathrm{e}^{5,77,87,105}$ & $--^{\mathrm{a}}$ \\
\hline \multicolumn{2}{|c|}{ Glucagon-like peptide I receptor } \\
\hline Exenatide ${ }^{5,100,108,109}$ & -- \\
\hline Liraglutide $\mathrm{e}^{5,9,102}$ & -- \\
\hline \multicolumn{2}{|c|}{ Inhibitors of dipeptidyl peptidate-4 } \\
\hline Alogliptin ${ }^{97-100}$ & Neutral \\
\hline Linagliptin $90,100,106,107$ & $-{ }^{\mathrm{a}}$ \\
\hline Saxagliptin ${ }^{100,103-105}$ & $-^{\mathrm{a}}$ \\
\hline Sitagliptin ${ }^{100-103}$ & $--^{\mathrm{a}}$ \\
\hline Insulin ${ }^{85,86,88,118}$ & $++^{\mathrm{a}}$ \\
\hline \multicolumn{2}{|c|}{ Insulin secretagogues } \\
\hline \multicolumn{2}{|c|}{ Meglitinides } \\
\hline Nateglinide ${ }^{5,95,96}$ & Neutral \\
\hline Repaglinide ${ }^{79,89,109, a}$ & $t^{\mathrm{a}}$ \\
\hline \multicolumn{2}{|l|}{ Sulfonylurea drugs } \\
\hline Chlorpropamide ${ }^{84-86}$ & ++ \\
\hline Gliclazide $^{75,80,94}$ & $+t^{\mathrm{a}}$ \\
\hline Glimepiride ${ }^{5,90-93}$ & $+\&-^{a}$ \\
\hline Glyburide $\mathrm{e}^{78,88,89}$ & $++^{\mathrm{a}}$ \\
\hline Tolbutamide $5,76,87$ & ++ \\
\hline \multicolumn{2}{|l|}{ Insulin sensitizers } \\
\hline \multicolumn{2}{|l|}{ Biguanides } \\
\hline Metformin ${ }^{5,75-78}$ & - \\
\hline \multicolumn{2}{|l|}{ Thiazolidinedione } \\
\hline Pioglitazone ${ }^{5,79-81}$ & ++ \\
\hline Rosiglitazone $\mathrm{e}^{78,82,83}$ & ++ \\
\hline \multicolumn{2}{|c|}{ SGLT2 inhibitors (or gliflozin) } \\
\hline Canagliflozin ${ }^{93,110,111}$ & -- \\
\hline Dapagliflozin ${ }^{1 / 2-1 / 4}$ & $--^{\mathrm{a}}$ \\
\hline Empagliflozin $^{115-117}$ & - \\
\hline
\end{tabular}

Notes: $+=>1 \mathrm{~kg}$. Neutral $= \pm 1 \mathrm{~kg}$. $-=<-1 \mathrm{~kg}$. Additional + or - refers to $\geq 3 \mathrm{~kg}$ weight

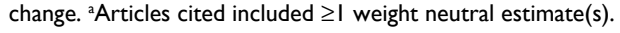

Insulin secretagogues are another alternative treatment option for diabetes. Sulfonylurea drugs such as chlorpropamide and tolbutamide are associated with weight gains of $2.6-5.3^{84,86}$ and $1.6-2.8 \mathrm{~kg},{ }^{5,76,87}$ respectively. This side effect associated with taking these medications may be why other more weight neutral sulfonylureas, such as glyburide $(-0.9$ to $\left.+1.6 \mathrm{~kg}^{78,88,89}\right)$, glimepiride $\left(-1.4\right.$ to $\left.+1.2 \mathrm{~kg}^{90,93}\right)$ and gliclazide $\left(-1.0\right.$ to $\left.+0.8 \mathrm{~kg}^{75,94}\right)$, are more frequently prescribed. It is important to note that patients who are given sulfonylureas as a first-line treatment regimen may experience greater weight gain. More pronounced gains of $3.6^{89}$ and $4.2 \mathrm{~kg}^{80}$ have been reported in patients prescribed glyburide and gliclazide as the first-line diabetes treatment, respectively. Other insulin secretagogues, such as meglitinides, are associated a lower risk of hypoglycemia and may be a more weight-favorable alternative than sulfonylurea drugs. Indeed, repaglinide and nateglinide are associated with weight neutral to lesser weight gain properties, with changes of -0.2 to $+1.8^{79,89,95}$ and $0.3-0.9$ $\mathrm{kg},{ }^{5,95,96}$ respectively.

Inhibitors of dipeptidyl peptidate-4 (DPP-4) are essentially weight neutral and include alogliptin, sitagliptin, saxagliptin and linagliptin. Alogliptin is the most weight neutral DDP-4 inhibitor and associated with a weight change of -0.9 to $+0.7 \mathrm{~kg} .{ }^{97-100}$ Conversely, sitagliptin, saxagliptin and linagliptin are associated with modest weight losses ranging from 0.1 to $-2.6,^{100-103} 2.1$ to $0.5^{100,103-105}$ and 2.1 to $0.6 \mathrm{~kg},,^{90,100,106,107}$ respectively. Acarbose, an $\alpha$-glucosidase inhibitor, is limited in its use due to gastrointestinal side effects, but is associated with modest weight loss of $0.4-2.8 \mathrm{~kg} .^{5,77,87,105}$

Recently, there have been two new classes of diabetes medications that have made it to the market: glucagon-like peptide-1 (GLP-1) agonists and sodium-glucose co-transporter 2 (SGLT-2) inhibitors with promising weight reduction properties. GLP-1s have been on the market slightly longer than SGLT-2 inhibitors. Unlike other antihyperglycemics, GLP-1R agonists are administered as an injection like insulin. Exenatide, a GLP-1 analog, is associated with weight loss ranging from 1.2 to $4.0 \mathrm{~kg},{ }^{5,100,108,109}$ while liraglutide $1.8 \mathrm{mg}$ is associated with slightly more modest weight loss of 1.7-3.4 kg. ${ }^{5,91,102}$ Additional information on the use of liraglutide $3.0 \mathrm{mg}$ as a weight management pharmaceutical (Saxenda $^{\circledR}$, Novo Nordisk A/S, Bagsværd, Denmark) can be found in the "Considerations for pharmaceutical treatment" section. In regards to SGLT-2 inhibitors, there are currently three approved medications in Canada that fall into this class of antihyperglycemic medication: canagliflozin, dapagliflozin and empaliflozin. Similar to GLP-1s, all of the approved medications in this class are associated with weight loss in clinical trials, with the greatest weight loss observed in patients taking canagliflozin (1.9-4.0 $\left.\mathrm{kg}^{93,110,111}\right)$, followed by dapagliflozin (1.0-4.5 $\left.\mathrm{kg}^{112,114}\right)$ and empaliflozin (1.5-2.9 $\left.\mathrm{kg}^{115,117}\right)$.

Weight gain is a well-known side effect of insulin and can range from 0.4 to $4.8 \mathrm{~kg} .{ }^{85,86,88,118}$ However, currently, insulin is the only treatment option for type 1 diabetics and is used for type 2 diabetics when they cannot tolerate or are not responsive to other hypoglycemics, which prevents the use of alternative treatments. There is considerable variability in the amount of weight gain associated with the use of insulin. Aside from genetics, other factors which can contribute to insulin-related weight gain, such as drug administration, dose and speed of release (rapid vs slow), can be manipulated to decrease the weight gain potential of this medication. For example, a study examining the weight and glycemic effects 
of once a day insulin injection vs the use of an intermediateacting insulin observed significantly greater weight gains in those using the intermediate compared to the once-daily insulin injection $(+1.9 \mathrm{vs}+0.4 \mathrm{~kg})$ over a 6 -month period. ${ }^{118}$

\section{Antihypertensives}

Hypertension is a prevalent condition among individuals with excess weight. In fact, gaining weight is associated with increases in both systolic and diastolic blood pressure. ${ }^{119}$ Dietary changes and weight management are typical firstline treatments for hypertension, ${ }^{120}$ and as such, medications which are associated with weight gain should be avoided. Fortunately, the majority of medications within this class appears to be weight neutral or associated with weight loss (Table 4).

Diuretics, more specifically hydrochlorothiazide, are associated with modest weight losses of $0.4-2.7 \mathrm{~kg} .{ }^{121-124}$

Table 4 Treatment-emergent weight changes associated with antihypertensives

\begin{tabular}{|c|c|}
\hline Drug name & Weight effect \\
\hline \multicolumn{2}{|l|}{ Alpha-blockers } \\
\hline Clonidine $^{155,156}$ & $t^{\mathrm{a}}$ \\
\hline Prazosin 157,158 & Neutral \\
\hline \multicolumn{2}{|l|}{ ACE inhibitors } \\
\hline Enalapril $^{131-133}$ & $--^{\mathrm{a}}$ \\
\hline Lisinopril| $24,137,138$ & $-^{\mathrm{a}}$ \\
\hline Perindopril ${ }^{134-136}$ & $+\&--^{\mathrm{a}}$ \\
\hline Ramipril ${ }^{|39-14|}$ & $-^{\mathrm{a}}$ \\
\hline \multicolumn{2}{|l|}{ ARBs } \\
\hline Irbesartan ${ }^{161,165,166}$ & Neutral \\
\hline Losartan $^{131,163,164}$ & $--^{\mathrm{a}}$ \\
\hline Olmesartan ${ }^{161,162,165}$ & Neutral \\
\hline Telmisartan ${ }^{159-162}$ & $-^{\mathrm{a}}$ \\
\hline Valsartan ${ }^{167-169}$ & $t^{\mathrm{a}}$ \\
\hline \multicolumn{2}{|l|}{ Beta-blockers } \\
\hline Acebutolol ${ }^{153,154}$ & Neutral \\
\hline Atenolol $143-145$ & $+t^{\mathrm{a}}$ \\
\hline Metoprolol ${ }^{148,149}$ & $t^{\mathrm{a}}$ \\
\hline Propranolol ${ }^{146,147}$ & $t^{\mathrm{a}}$ \\
\hline Timolol ${ }^{150-152}$ & $--^{\mathrm{a}}$ \\
\hline \multicolumn{2}{|l|}{ CCBs } \\
\hline Amlodipine ${ }^{170-172}$ & Neutral \\
\hline Diltiazem $^{173-175}$ & $+^{\mathrm{a}}$ \\
\hline \multicolumn{2}{|l|}{ Direct renin inhibitors } \\
\hline Aliskiren ${ }^{176-178}$ & Neutral \\
\hline \multicolumn{2}{|l|}{ Diuretics } \\
\hline Chlorthalidone ${ }^{122,125,126, a}$ & $--^{\mathrm{a}}$ \\
\hline Furosemide ${ }^{122,123,130 \mathrm{a}}$ & -- \\
\hline Hydrochlorothiazide $\mathrm{e}^{|2|-124, \mathrm{a}}$ & $--^{\mathrm{a}}$ \\
\hline Indapamide ${ }^{127-129, a}$ & $--^{\mathrm{a}}$ \\
\hline
\end{tabular}

Notes: $+=>\mid \mathrm{kg}$. Neutral $= \pm \mathrm{l} \mathrm{kg}$. change. ${ }^{\text {aArticles }}$ cited included $\geq 1$ weight neutral estimate(s).

Abbreviations: ACE, angiotensin converting enzyme; ARB, angiotensin II receptor blocker; CCB, calcium channel blocker.
This is a consistent characteristic of this class of medication, with other commonly prescribed diuretics including chlorthalidone ( -1.8 to $\left.0.2 \mathrm{~kg}^{122,125,126}\right)$, indapamide $(-2.7$ to $\left.0.5 \mathrm{~kg}^{127,129}\right)$ and furosemide $\left(-4.1\right.$ to $\left.+0.3 \mathrm{~kg}^{122,123,130}\right)$ being similarly associated with weight neutral to weight loss effects.

Of the commonly prescribed angiotensin-converting enzyme inhibitors, enalapril $\left(-3.0\right.$ to $\left.+0.4 \mathrm{~kg}^{131,133}\right)$ and perindopril $\left(-3.2\right.$ to $\left.+1.1 \mathrm{~kg}^{134,136}\right)$ are associated with the greatest amount of weight loss. Lisinopril $\left(-1.5\right.$ to $\left.0.0 \mathrm{~kg}^{124,137,138}\right)$ and ramipril $\left(-1.5\right.$ to $\left.+1.0 \mathrm{~kg}^{139,141}\right)$ may also be associated with weight loss, but appear to be more weight neutral.

Beta-blockers are typically associated with weight gain for the first few months of treatment, followed by a plateau. However, the amount of weight gain associated with betablockers is moderate and may not be clinically significant. ${ }^{142}$ Of the commonly prescribed beta-blockers, atenolol $(-0.5$ to $\left.+3.4 \mathrm{~kg}^{143,145}\right)$, propranolol $\left(-0.5\right.$ to $\left.+2.3 \mathrm{~kg}^{146,147}\right)$ and metoprolol (1.2-2.0 $\left.\mathrm{kg}^{148,149}\right)$ are associated with the highest weight gain. Conversely, timolol $\left(-1.8\right.$ to $\left.+0.4 \mathrm{~kg}^{150,152}\right)$ and acebutolol ( -0.6 to $\left.0.0 \mathrm{~kg}^{153,154}\right)$ appear to be weight neutral and may even have some weight loss properties. For alphablockers, weight gain is not a commonly reported side effect. In general, changes in weight for alpha-blockers appear to be minor or nonexistent, with the average changes in weight following clonidine $\left(0.4-1.4 \mathrm{~kg}^{155,156}\right)$ and prazosin $(0.0-0.5$ $\left.\mathrm{kg}^{157,158}\right)$ being $<1.5 \mathrm{~kg}$.

Angiotensin II receptor blockers and calcium channel blockers are the second-line treatment options for hypertension that are commonly compared in efficacy trials. Of the most commonly used angiotensin II receptor blockers, telmisartan $\left(-2.1\right.$ to $\left.+0.2 \mathrm{~kg}^{159,162}\right)$ and losartan $\left(-4.2\right.$ to $\left.-0.1 \mathrm{~kg}^{131,163,164}\right)$ are associated with the greatest amount of weight loss. Olmesartan $\left(-0.5\right.$ to $\left.+0.3 \mathrm{~kg}^{161,162,165}\right)$ and irbesartan $\left(-1.0\right.$ to $\left.+0.2 \mathrm{~kg}^{161,165,166}\right)$ are associated with weight neutral effects and valsartan (0.6-2.4 $\left.\mathrm{kg}^{167,169}\right)$ is primarily weight neutral, but can be associated with modest weight gains. Conversely, the two most commonly used calcium channel blockers, amlodipine $\left(-0.7\right.$ to $\left.+0.8 \mathrm{~kg}^{170,172}\right)$ and diltiazem $\left(-0.1\right.$ to $\left.+1.2 \mathrm{~kg}^{173,175}\right)$, are relatively weight neutral with $<1.5 \mathrm{~kg}$ weight changes on average.

In 2008, a new class of hypertension medications was approved for use in Canada, called direct renin inhibitors. Currently, aliskiren is the only medication within this class approved for use and appears to have weight neutral effects $\left(0.0-1.0 \mathrm{~kg}^{176,178}\right)$.

\section{Corticosteroids}

Corticosteroids including cortisone and other glucocorticosteroids can be used for the treatment of conditions such 
as asthma, dermatological or inflammatory disorders and rheumatic or autoimmune diseases. ${ }^{179}$ The short-term use of corticosteroids has not been shown to be associated with significant changes in body weight ${ }^{180}$ (Table 5). Conversely, literature on the long-term usage ( $\geq 3$ months) of corticosteroids suggests the opposite, ${ }^{181}$ with prednisone (1.7-5.8 $\left.\mathrm{kg}^{182,184}\right)$, prednisolone $\left(1.5-4.4 \mathrm{~kg}^{185,186}\right)$ and cortisone $\left(1.5-8.4 \mathrm{~kg}^{187,189}\right)$ being associated with significant weight gains. Additionally, there is considerable variability in the amount of weight gain that patients will experience while taking this class of medication, with one study reporting weight gains of $\geq 10 \mathrm{~kg}$ in more than one-fifth of patients taking prednisone at 1 year. ${ }^{182}$ Very few alternatives exist for the use of corticosteroids. However, changes in treatment regimen can be useful in reducing weight increases. ${ }^{190}$ Alternate day dosing schedule for prednisone may be beneficial as it has been shown to attenuate weight gains and even promote weight loss. ${ }^{190}$

\section{Considerations for pharmaceutical treatment}

Improving clinical indicators and patient's health is paramount when selecting pharmaceutical treatment options and there are several factors that need to be taken into consideration. Given that weight gain is a commonly reported side effect for many medications, clinicians should strive to prescribe medication(s) with more favorable weight-related outcomes whenever clinically possible. With the overwhelming evidence of the health risk of excess weight and the association of gaining weight and nonadherence to medication, it is important to discuss and evaluate this potential side effect with the patient when prescribing a medication.

In order for fluctuations in weight to be monitored, baseline weight measurements should be taken prior to initiating a pharmaceutical treatment. A weight gain of $>2.0 \mathrm{~kg}$ within a month, in the absence of health and lifestyle changes suggests that intervention may be necessary. ${ }^{8}$ Prior to making changes to medication, changes to dietary and physical activity may be able to counteract the weight gaining effects of medications. Indeed, research

Table 5 Treatment-emergent weight changes associated with corticosteroids

\begin{tabular}{ll}
\hline Drug name & Weight effect \\
\hline Cortisone $^{187-189}$ & ++ \\
Prednisolone $^{185,186}$ & ++ \\
Prednisone $^{182-184}$ & ++ \\
\hline
\end{tabular}

Notes: $+=>1$ kg. Additional + refers to $\geq 3$ kg weight change. has suggested that individuals taking psychiatric medications that are associated with weight gain can still lose a clinically significant amount of weight by participating in a lifestyle intervention without the need to alter their medication. ${ }^{191,192}$ If lifestyle changes alone do not result in the desired amount of weight loss, changes to medication should be considered. Where possible, changes to the dose or delivery of the medication should be attempted prior to medication substitution. When it is not feasible, clinicians should consider substituting medications. Fortunately, many of the medications examined in this review have more weight-favorable outcomes.

Once the decision has been made to change medications, clinicians should be cognizant to switch only one medication at a time, so that the effects on weight and medical efficacy can be appropriately evaluated. ${ }^{190}$ A protocol highlighting clear instructions should be created for the patient to minimize the potential of withdrawal symptoms. When switching to a more weight-favorable medication, non-weight-related side effects must also be taken into consideration. For example, while bupropion is often recommended as an alternative therapy to other antidepressants due to its weight loss side effects, it is also associated with a risk of seizures. Further, cost is an important consideration as it can contribute to nonadherence. This may be the case with liraglutide 1.8 $\mathrm{mg}$, which is associated with a better side effect and weight profile than other antihyperglycemic medications, but costs considerably more.

During the course of treatment, switching pharmacotherapies may not be feasible due to a variety of reasons such as cost and efficacy. In such cases, adjunctive therapies may be used to better manage treatment-induced weight gain. Currently, there are three medications approved for weight management in Canada. Orlistat, a lipase inhibitor, has been available since the 1970s and is associated with placebo-subtracted weight losses of $4.3 \mathrm{~kg} .{ }^{193}$ Unfortunately, the common side effects of this medication include oily and loose stools, which can ultimately lead to nonadherence and discontinuation. In comparison, liraglutide $3.0 \mathrm{mg}$, at a clinical dose of $3.0 \mathrm{mg}$, is also approved for weight management and has been associated with placebo-subtracted weight losses of 4.5-6.0 $\mathrm{kg} .{ }^{4,27}$ While there are beneficial effects such as improved HbA1c levels, there are some more severe rare side effects such as gallstones and pancreatitis. ${ }^{194}$ In 2018, Health Canada approved Contrave, which is a combination medication of bupropion, an norepinephrine-dopamine reuptake inhibitor, and naltrexone, an opiate antagonist. Results of a Phase 3 clinical trial suggest that the use of Contrave, as an adjunct 
to a lifestyle intervention, results in superior weight loss to placebo $(5.0 \%-6.1 \%$ vs $1.3 \%)$, but as with other weight management medications, nausea appears to be a common side effect. ${ }^{195}$

Where it is not possible to add an adjunctive therapy due to drug interactions or cost, patients should be made aware of the weight change potential, and research suggests that implementing lifestyle changes (ie, quality of diet and increased physical activity) may be beneficial to combat the weight gaining effects. For example, a study which compared metformin therapy alone and in addition to a lifestyle modification program observed greater weight loss in the group participating in the lifestyle modification (5.6 vs $2.1 \mathrm{~kg}^{196}$ ).

There are several limitations that warrant mentioning. Due to the number of pharmaceuticals approved for treatment worldwide, it is not possible to examine the weight effect of every agent. As such, this review is not an exhaustive list, rather it evaluates commonly used pharmaceuticals that have been approved for use in Canada. The effect of pharmaceutical medications on weight depends of a multitude of factors; thus, the associations in this paper need to be interpreted with caution. As population demographics have shifted dramatically in the last 30 years, findings of studies examined may be dated and may not be generalizable to the population today. Patient demographics are an important consideration because differences in age, sex, body mass index and so on may have a significant impact on the weight changes that occur. Specifically, the weight gains associated with lithium are more severe in patients with obesity than their lowerweight counterparts $\left(6.1 \mathrm{~kg}\right.$ obese vs $1.1 \mathrm{~kg}$ non-obese $\left.{ }^{32}\right)$. Conversely, the weight gains associated with olanzapine are lower with increasing body mass index. ${ }^{197}$ Further, this paper provides the mean ranges of absolute weight change, which may be useful for interpreting the impact of medication on weight change. However, these ranges merely reflect the results of available studies, some of which have small sample sizes (ie, $n<10)$ and may not be generalizable to a heterogeneous population. As studies differ in treatment duration, dose, concomitant medications and intervention type, changes in weight observed in clinical practice may be different from the results presented here. For example, the duration of treatment has a significant impact on the weight outcome of patients for some medications. In one study, patients plateaued after 37 weeks of olanzapine treatment, ${ }^{197}$ while another study observed that patients taking clozapine may persist in gaining weight after 46 months. ${ }^{198}$ Given that weight gain is a complex and multifactorial issue, it may be possible that other factors contribute to the reported weight changes. Several of the studies examined did not account for potential confounding factors such as lifestyle changes. This may be especially pertinent in the case with glucocorticoids, where the results from a recent systematic review suggest that dietary intake is infrequently reported, making it difficult to assess weight changes. ${ }^{179}$ However, as the course of pharmaceutical treatment does not occur independently of side effects such as weight gain, the estimates reported are still relevant to clinical practice.

\section{Conclusion}

Medication-induced weight gain can be frustrating for both patients and health care professionals. The increased use of pharmaceuticals in the past decade may, in part, contribute to the increasing rates of overweight and obesity globally. Excess weight has been shown to result in the development of many of the diseases treated by medications and to be associated with worse treatment outcomes. Further, due to the obesogenic effects of many pharmacotherapies, and poor long-term success in weight loss interventions, the assessment of the weight gain potential associated with medicinal treatment is of particular importance for individuals who already are overweight or obese and in patients with chronic disease.

This paper provides considerable options for selecting medications and summarizes the available literature on the effects of these common medications on weight change. Clinicians should select medications associated with more favorable weight profiles when first initiating treatment, or consider changing medications if patients are experiencing the weight gaining side effects, if clinically possible. When it is not feasible to change medications, adjunctive therapies or lifestyle intervention may help to combat weight gaining side effects.

\section{Disclosure}

SW is the Medical Director of the Wharton Medical Clinic and maintains privileges at Toronto East General Hospital and Hamilton Health Sciences. SW has previously received grants from CIHR and Mitacs, and has payment from Novo Nordisk, Eli Lilly, Janssen and Astra Zeneca for advisory work. SW and RAGC are currently working with Novo Nordisk for the completion of pharmaceutical manuscript(s). RAGC is also the Research Coordinator at the Wharton Medical Clinic. The authors report no other conflicts of interest in this work.

\section{References}

1. Rotermann M, Sanmartin C, Hennessy D, Arthur M. Prescription medication use by Canadians aged 6 to 79. Health Rep. 2014;25:3-9. 
2. Centre for Disease Control and Prevention Staff. Therapeutic Drug Use (2017). Available from: https://www.cdc.gov/nchs/fastats/druguse-therapeutic.htm. Accessed January, 2018.

3. Leslie WS, Hankey CR, Lean MEJ. Weight gain as an adverse effect of some commonly prescribed drugs: a systematic review. $Q M J$. 2007; 100:395-404.

4. Verhaegen AA, van Gaal LF. Drug-induced obesity and its metabolic consequences: a review with a focus on mechanisms and possible therapeutic options. J Endocrinol Invest. 2017;40:1165-1174.

5. Domecq JP, Prutsky G, Leppin A, et al. Drugs commonly associated with weight change: a systematic review and meta-analysis. J Clin Endocrinol Metab. 2015;100:363-370.

6. Virk S, Schwartz TL, Jindal S, Nihalani N, Jones N. Psychiatric medication induced obesity: an aetiologic review. Obes Rev. 2004;5(3):167-170.

7. Dent R, Blackmore A, Peterson J, et al. Changes in body weight and psychotropic drugs: a systematic synthesis of the literature. PLoS One. 2012;7:1-13

8. Malone M. Medications associated with weight gain. Ann Pharmacother. 2005;39(12):2046-2055.

9. Monteleone P, Martiadis V, Maj M. Management of schizophrenia with obesity, metabolic, and endocrinological disorders. Psychiatr Clin North Am. 2009;32(4):775-794.

10. Serretti A, Mandelli L. Antidepressants and body weight: a comprehensive review and meta-analysis. J Clin Psychiatry. 2010;71(10):1259-1272.

11. Frankenburg FR, Zanarini MC, Kando J, Centorrino F. Clozapine and body mass change. Biol Psychiatry. 1998;43(7):520-524.

12. Leadbetter R, Shutty M, Pavalonis D, Vieweg V, Higgins P, Downs M. Clozapine-induced weight gain: prevalence and clinical relevance. $\mathrm{Am}$ J Psychiatry. 1992;149(1):68-72.

13. Allison DB, Mentore JL, Heo M, et al. Antipsychotic-induced weight gain: a comprehensive research synthesis. Am J Psychiatry. 1999;156(11):1686-1696.

14. Zipursky R, Gu H, Green AI, et al. Clinical correlates of weight gain in first episode psychosis patients treated with olanzapine. Schizophr Res. 2003;60(1):372.

15. Mcquade RD, Stock E, Marcus R, et al. A comparison of weight change during treatment with olanzapine or aripiprazole: results from a randomized, double-blind study. J Clin Psychiatry. 2004;65(Suppl 1):47-56.

16. Breier A, Berg PH, Thakore $\mathrm{JH}$, et al. Olanzapine versus ziprasidone: results of a 28-week double-blind study in patients with schizophrenia. Am J Psychiatry. 2005;162(10):1879-1887.

17. Kane JM, Detke HC, Naber D, et al. Olanzapine long-acting injection: a 24-week, randomized, double-blind trial of maintenance treatment in patients with schizophrenia. Am J Psychiatry. 2010;167(2):181-189.

18. Trethowan W, Scott P. Chlorpromazine in obsessive-compulsive and allied disorders. Lancet. 1955;265:781-785.

19. Ayd FJ. Prolonged administration of chlorpromazine (thorazine) hydrochloride: clinical and laboratory survey of fifty patients. $\mathrm{J} \mathrm{Am}$ Med Assoc. 1959;169:1296-1301.

20. Leucht S, Cipriani A, Spineli L, et al. Comparative efficacy and tolerability of 15 antipsychotic drugs in schizophrenia: a multipletreatments meta-analysis. Lancet. 2013;382:951-962.

21. Brecher M, Leong RW, Stening G, Osterling-Koskinen L, Jones AM. Quetiapine and long-term weight change: a comprehensive data review of patients with schizophrenia. J Clin Psychiatry. 2007;68(4): 597-603.

22. Brecher M, Rak IW, Melvin K, Jones AM. The long-term effect of quetiapine $\left(\right.$ Seroquel $^{\mathrm{TM}}$ ) monotherapy on weight in patients with schizophrenia. Int J Psychiatry Clin Pract. 2000;4(4):287-291.

23. Zipursky RB, Gu H, Green AI, et al. Course and predictors of weight gain in people with first-episode psychosis treated with olanzapine or haloperidol. Br J Psychiatry. 2005;187(06):537-543.

24. Weiden PJ, Cutler AJ, Polymeropoulos MH, Wolfgang CD. Safety profile of iloperidone: a pooled analysis of 6-week acute-phase pivotal trials. J Clin Psychopharmacol. 2008;28(2 Suppl 1):S12-S19.
25. de Hert M, Mittoux A, He Y, Peuskens J. Metabolic parameters in the short- and long-term treatment of schizophrenia with sertindole or risperidone. Eur Arch Psychiatry Clin Neurosci. 2011;261(4):231-239.

26. de Hert M, Yu W, Detraux J, Sweers K, van Winkel R, Correll CU. Body weight and metabolic adverse effects of asenapine, iloperidone, lurasidone and paliperidone in the treatment of schizophrenia and bipolar disorder: a systematic review and exploratory meta-analysis. CNS Drugs. 2012;26:733-759.

27. Gopal S, Vijapurkar U, Lim P, Morozova M, Eerdekens M, Hough D. A 52-week open-label study of the safety and tolerability of paliperidone palmitate in patients with schizophrenia. J Psychopharmacol. 2011;25(5):685-697.

28. Nakamura M, Ogasa M, Guarino J, et al. Lurasidone in the treatment of acute schizophrenia: a double-blind, placebo-controlled trial. J Clin Psychiatry. 2009;70(6):829-836.

29. Keck PE, Marcus R, Tourkodimitris S, et al. A placebo-controlled, double-blind study of the efficacy and safety of aripiprazole in patients with acute bipolar mania. Am J Psychiatry. 2003;160(9):1651-1658.

30. Vendsborg PB, Bech P, Rafaelsen OJ. Lithium treatment and weight gain. Acta Psychiatr Scand. 1976;53:139-147.

31. Peselow ED, Dunner DL, Fieve RR, Lautin A. Lithium carbonate and weight gain. J Affect Disord. 1980;2:303-310.

32. Bowden CL, Calabrese JR, Ketter TA, Sachs GS, White RL, Thompson TR. Impact of lamotrigine and lithium on weight in obese and nonobese patients with bipolar I disorder. Am J Psychiatry. 2006;163(7):1199-1201.

33. Coxhead N, Silverstone T, Cookson J. Carbamazepine versus lithium in the prophylaxis of bipolar affective disorder. Acta Psychiatr Scand. 1992;85:114-118.

34. Pickrell WO, Lacey AS, Thomas RH, Smith PE, Rees MI. Weight change associated with antiepileptic drugs. J Neurol Neurosurg Psychiatry. 2013;84(7):796-799.

35. Corman CL, Leung NM, Guberman AH. Weight gain in epileptic patients during treatment with valproic acid: a retrospective study. Can J Neurol Sci. 1997;24:240-244.

36. Biton V, Mirza W, Montouris G, Vuong A, Hammer AE, Barrett PS. Weight change associated with valproate and lamotrigine monotherapy in patients with epilepsy. Neurology. 2001;56(2):172-177.

37. Tohen M, Bowden CL, Smulevich AB, et al. Olanzapine plus carbamazepine v. carbamazepine alone in treating manic episodes. $\mathrm{Br} J$ Psychiatry. 2008;192(2):135-143.

38. Lindsley CW. The top prescription drugs of 2011 in the United States: antipsychotics and antidepressants once again lead CNS therapeutics. ACS Chem Neurosci. 2012;3:630-631.

39. Berken GH, Weinstein DO, Stern WC. Weight gain. A side-effect of tricyclic antidepressants. J Affect Disord. 1984;7:133-138.

40. Fernstrom MH, Kupfer DJ. Antidepressant-induced weight gain: a comparison study of four medications. Psychiatry Res. 1988;26:265-271.

41. Szarek BL, Brandt DM. A comparison of weight changes with fluoxetine, desipramine, and amitriptyline: a retrospective study of psychiatric inpatients. J Nerv Ment Dis. 1993;181(11):702-704.

42. Blumenthal SR, Castro VM, Clements CC, et al. An electronic health records study of long-term weight gain following antidepressant use. JAMA Psychiatry. 2014;71(8):889.

43. Remick RA, Claman J, Reesal R, et al. Comparison of fluoxetine and desipramine in depressed outpatients. Curr Ther Res. 1993;53:457-465.

44. Frank E, Kupfer DJ, Bulik CM, Levenson JA. Imipramine and weight gain during the treatment of recurrent depression. J Affect Disord. 1990;20:165-172.

45. Pande AC, Grunhaus LJ, Haskett RF, Greden JF. Weight change with antidepressant treatment. Biol Psychiatry. 2017;25:A55

46. Edwards NB, Murphy JK, Downs AD, Ackerman BJ, Rosenthal TL. Doxepin as an adjunct to smoking cessation: a double-blind pilot study. Am J Psychiatry. 1989;146:373-376.

47. Feighner J, Hendrickson G, Miller L, Stern W. Double-blind comparison of doxepin versus bupropion in outpatients with a major depressive disorder. J Clin Psychopharmacol. 1986;6:27-32. 
48. Feighner JP, Cohn JB. Double-blind comparative trials of fluoxetine and doxepin in geriatric patients with major depressive disorder. J Clin Psychiatry. 1985;46:20-25.

49. Rabkin JG, Quitkin FM, Mcgrath P, Harrison W, Tricamo E. Adverse reactions to monoamine oxidase inhibitors. Part II. Treatment correlates and clinical management. J Clin Psychopharmacol. 1985;5:2-9.

50. Falk WE, Rosenbaum JF, Otto MW, Zusky PM, Weilburg JB, Nixon RA. Fluoxetine versus trazodone in depressed geriatric patients. $J$ Geriatr Psychiatry Neurol. 1989;2(4):208-214.

51. Weisler RH, Johnston JA, Lineberry CG, Samara B, Branconnier RJ, Billow AA. Comparison of bupropion and trazodone for the treatment of major depression. J Clin Psychopharmacol. 1994;14(3):170-179.

52. Cunningham LA, Borison RL, Carman JS, et al. A comparison of venlafaxine, trazodone, and placebo in major depression. J Clin Psychopharmacol. 1994;14:99-106.

53. Cantú TG, Korek JS. Monoamine oxidase inhibitors and weight gain. Drug Intell Clin Pharm. 1988;22:755-759.

54. Bieck PR, Firkusny L, Schick, et al. Monoamine oxidase inhibition by phenelzine and brofaromine in healthy volunteers. Clin Pharmacol Ther. 1989;45:260-269.

55. Evans DL, Davidson J, Raft D. Early and late side effects of phenelzine. J Clin Psychopharmacol. 1982;2:208-210.

56. Himmelhoch JM, Thase ME, Mallinger AG, Houck P. Tranylcypromine versus imipramine in anergic bipolar depression. Am J Psychiatry 1991;148:910-916.

57. Davidson J, Turnbull C. Loss of Appetite and Weight Associated with the Monoamine Oxidase Inhibitor Isocarboxazid. J Clin Psychopharmacol. 1982;2:263-265.

58. Burnet J. Treatment of anxiety states by antidepressant drugs. Br Med J. 1955;1:906-104.

59. Bouwer CD, Harvey BH. Phasic craving for carbohydrate observed with citalopram. Int Clin Psychopharmacol. 1996;11:273-278.

60. Colonna L, Andersen HF, Reines EH. A randomized. double-blind, 24-week study of escitalopram (10 mg/day) versus citalopram (20 $\mathrm{mg}$ /day) in primary care patients with major depressive disorder. Curr Med Res Opin. 2005;21:1659-1668.

61. Maina G, Albert U, Salvi V, Bogetto F. Weight gain during long-term treatment of obsessive-compulsive disorder: a prospective comparison between serotonin reuptake inhibitors. J Clin Psychiatry. 2004;65:1365-1371.

62. Abell CA, Farquhar DL, Galloway SM, Steven F, Philip AE, Munro JF. Placebo controlled double-blind trial of fluvoxamine maleate in the obese. J Psychosom Res. 1986;30(2):143-146.

63. Westenberg HG, Stein DJ, Yang H, Li D, Barbato LM. A double-blind placebo-controlled study of controlled release fluvoxamine for the treatment of generalized social anxiety disorder. J Clin Psychopharmacol. 2004;24(1):49-55.

64. Pigott TA, Prakash A, Arnold LM, Aaronson ST, Mallinckrodt CH, Wohlreich MM. Duloxetine versus escitalopram and placebo: an 8-month, double-blind trial in patients with major depressive disorder. Curr Med Res Opin. 2007;23(6):1303-1318.

65. Wise TN, Perahia DGS, Pangallo BA, Losin WG, Wiltse CG. Effects of the antidepressant duloxetine on body weight: analyses of 10 clinical studies. Prim Care Companion J Clin Psychiatry. 2006;8:269-278.

66. Croft H, Settle E, Houser T, Batey SR, Donahue RM, Ascher JA. A placebo-controlled comparison of the antidepressant efficacy and effects on sexual functioning of sustained-release bupropion and sertraline. Clin Ther. 1999;21(4):643-658.

67. Søgaard J, Lane R, Latimer P, et al. A 12-week study comparing moclobemide and sertraline in the treatment of outpatients with atypical depression. J Psychopharmacol. 1999;13(4):406-414.

68. Tourian KA, Leurent C, Graepel J, Ninan PT. Desvenlafaxine and weight change in major depressive disorder. Prim Care Companion J Clin Psychiatry. 2010;12(1):PCC.08m00746.

69. Tourian KA, Pitrosky B, Padmanabhan SK, Rosas GR. A 10-month, open-label evaluation of desvenlafaxine in outpatients with major depressive disorder. Prim Care Companion CNS Disord. 2011;13(2).
70. Mcintyre RS, Fayyad RS, Guico-Pabia CJ, Boucher M. A post hoc analysis of the effect of weight on efficacy in depressed patients treated with desvenlafaxine $50 \mathrm{mg} / \mathrm{d}$ and $100 \mathrm{mg} / \mathrm{d}$. Prim Care Companion CNS Disord. 2015;17(3). eCollection 2015.

71. Guelfi JD, Ansseau M, Timmerman L, Kørsgaard S; MirtazapineVenlafaxine Study Group. Mirtazapine versus venlafaxine in hospitalized severely depressed patients with melancholic features. J Clin Psychopharmacol. 2001;21:425-431.

72. Kraus T, Haack M, Schuld A, Hinze-Selch D, Koethe D, Pollmächer T Body weight, the tumor necrosis factor system, and leptin production during treatment with mirtazapine or venlafaxine. Pharmacopsychiatry. 2002;35(6):220-225.

73. Clement M, Harvey B, Rabi DM, Roscoe RS, Sherifali D. Canadian Diabetes Association 2013 clinical practice guidelines for the prevention and management of diabetes in Canada. Can J Diabetes. 2013;37:S20-S25.

74. Bristol-Myers Squibb Co. Glucophage(r) XR Product Monograph (2008). Available from: https://www.accessdata.fda.gov/drugsatfda_docs/label/2008/020357s031,021202s016lbl.pdf. Accessed November 20, 2017.

75. Tessier D, Maheux P, Khalil A, Fülöp T. Effects of gliclazide versus metformin on the clinical profile and lipid peroxidation markers in type 2 diabetes. Metabolism. 1999;48:897-903.

76. Josephkutty S, Potter JM. Comparison of tolbutamide and metformin in elderly diabetic patients. Diabet Med. 1990;7:510-514.

77. Wang N, Zhang JP, Xing XY, et al. Associations between changes in glucagon-like peptide-1 and bodyweight reduction in patients receiving acarbose or metformin treatment. J Diabetes. 2017;9(8):728-737.

78. Kahn SE, Haffner SM, Heise MA, et al. Glycemic durability of rosiglitazone, metformin, or glyburide monotherapy. $N$ Engl J Med. 2006;355:2427-2443.

79. Jovanovic L, Hassman DR, Gooch B, et al. Treatment of type 2 diabetes with a combination regimen of repaglinide plus pioglitazone. Diabetes Res Clin Pract. 2004;63(2):127-134.

80. Tan MH, Baksi A, Krahulec B, et al. Comparison of pioglitazone and gliclazide in sustaining glycemic control over 2 years in patients with type 2 diabetes. Diabetes Care. 2005;28(3):544-550.

81. Smith SR, de Jonge L, Volaufova J, Li Y, Xie H, Bray GA. Effect of pioglitazone on body composition and energy expenditure: a randomized controlled trial. Metabolism. 2005;54(1):24-32.

82. Phillips LS, Grunberger G, Miller E, et al. Once- and twice-daily dosing with rosiglitazone improves glycemic control in patients with type 2 diabetes. Diabetes Care. 2001;24(2):308-315.

83. Raskin P, Rendell M, Riddle MC, et al. A randomized trial of rosiglitazone therapy in patients with inadequately controlled insulin-treated type 2 diabetes. Diabetes Care. 2001;24(7):1226-1232.

84. Clarke BF, Campbell IW. Comparison of metformin and chlorpropamide in non-obese, maturity-onset diabetics uncontrolled by diet. $\mathrm{Br}$ Med J. 1977;2(6102):1576-1578.

85. United Kingdom Prospective Diabetes Study (UKPDS). Relative efficacy of randomly allocated diet, sulphonylurea, insulin, or metformin in patients with newly diagnosed non-insulin dependent diabetes followed for three years. BMJ. 1995;310:83-88.

86. United Kingdom Prospective Diabetes Study (UKPDS). Intensive blood-glucose control with sulphonylureas or insulin compared with conventional treatment and risk of complications in patients with type 2 diabetes. Lancet. 1998;352:837-853.

87. Coniff RF, Shapiro JA, Seaton TB, Bray GA. Multicenter, placebocontrolled trial comparing acarbose (BAY g 5421) with placebo, tolbutamide, and tolbutamide-plus-acarbose in non-insulin-dependent diabetes mellitus. Am J Med. 1995;98:443-451.

88. Herz M, Sun B, Milicevic Z, et al. Comparative efficacy of preprandial or postprandial Humalog Mix 75/25 versus glyburide in patients 60 to 80 years of age with type 2 diabetes mellitus. Clin Ther. 2002;24(1):73-86

89. Marbury T, Huang WC, Strange P, Lebovitz H. Repaglinide versus glyburide: a one-year comparison trial. Diabetes Res Clin Pract. 1999;43:155-166. 
90. Gallwitz B, Rosenstock J, Emser A, von Eynatten M, Woerle H-J. Linagliptin is more effective than glimepiride at achieving a composite outcome of target $\mathrm{HbA}_{1 \mathrm{c}}<7 \%$ with no hypoglycaemia and no weight gain over 2 years. Int J Clin Pract. 2013;67:317-321.

91. Yang W, Chen L, Ji Q, et al. Liraglutide provides similar glycaemic control as glimepiride (both in combination with metformin) and reduces body weight and systolic blood pressure in Asian populations with type 2 diabetes from China, South Korea and India: a 16-week randomized, double-blind, active control trial. Diabetes Obes Metab. 2011;13(1):81-88.

92. Garber A, Henry R, Ratner R, et al. Liraglutide versus glimepiride monotherapy for type 2 diabetes (LEAD-3 Mono): a randomised, 52-week, Phase III, double-blind, parallel-treatment trial. Lancet. 2009;373(9662):473-481.

93. Leiter LA, Yoon KH, Arias P, et al. Canagliflozin provides durable glycemic improvements and body weight reduction over 104 weeks versus glimepiride in patients with type 2 diabetes on metformin: a randomized, double-blind, Phase 3 study. Diabetes Care. 2015;38(3):355-364.

94. Ammari F, Davies MJ, Koppiker N, Gregory R, Burden AC. The effect of gliclazide on plasma insulin, intact and 32/33 split proinsulin in South Asian subjects with type 2 diabetes mellitus. Diabet Med. 1999;16:142-146.

95. Rosenstock J, Hassman DR, Madder RD, et al. Repaglinide versus nateglinide monotherapy: a randomized, multicenter study. Diabetes Care. 2004;27(6):1265-1270.

96. Saloranta C, Hershon K, Ball M, Dickinson S, Holmes D. Efficacy and safety of nateglinide in type 2 diabetic patients with modest fasting hyperglycemia. J Clin Endocrinol Metab. 2002;87:4171-4176.

97. Rosenstock J, Wilson C, Fleck P. Alogliptin versus glipizide monotherapy in elderly type 2 diabetes mellitus patients with mild hyperglycaemia: a prospective, double-blind, randomized, 1-year study. Diabetes Obes Metab. 2013;15:906-914.

98. del Prato S, Camisasca R, Wilson C, Fleck P. Durability of the efficacy and safety of alogliptin compared with glipizide in type 2 diabetes mellitus: a 2-year study. Diabetes Obes Metab. 2014;16:1239-1246.

99. Pratley RE, Kipnes MS, Fleck PR, Wilson C, Mekki Q. Efficacy and safety of the dipeptidyl peptidase-4 inhibitor alogliptin in patients with type 2 diabetes inadequately controlled by glyburide monotherapy. Diabetes Obes Metab. 2009;11:167-176.

100. Aroda VR, Henry RR, Han J, et al. Efficacy of GLP-1 receptor agonists and DPP-4 inhibitors: meta-analysis and systematic review. Clin Ther. 2012;34(6):1247-1258.e22.

101. Nauck MA, Meininger G, Sheng D, Terranella L, Stein PP; Sitagliptin Study 024 Group. Efficacy and safety of the dipeptidyl peptidase-4 inhibitor, sitagliptin, compared with the sulfonylurea, glipizide, in patients with type 2 diabetes inadequately controlled on metformin alone: a randomized, double-blind, non-inferiority trial. Diabetes Obes Metab. 2007;9(2):194-205.

102. Pratley RE, Nauck M, Bailey T, et al. Liraglutide versus sitagliptin for patients with type 2 diabetes who did not have adequate glycaemic control with metformin: a 26-week, randomised, parallel-group, openlabel trial. Lancet. 2010;375(9724):1447-1456.

103. Asti A, D'Alessandro A, Zito FP, et al. Sitagliptin versus saxagliptin in decompensated type 2 diabetes mellitus patients. Ital J Med. 2016;10(1):36-41.

104. Rosenstock J, Sankoh S, List JF. Glucose-lowering activity of the dipeptidyl peptidase-4 inhibitor saxagliptin in drug-naive patients with type 2 diabetes. Diabetes Obes Metab. 2008;10:376-386.

105. du J, Liang L, Fang H, et al. Efficacy and safety of saxagliptin compared with acarbose in Chinese patients with type 2 diabetes mellitus uncontrolled on metformin monotherapy: results of a Phase IV openlabel randomized controlled study (the SMART study). Diabetes Obes Metab. 2017;19(11):1513-1520.

106. Johansen O, Neubacher D, von Eynatten M, Patel S, Woerle H-J. Cardiovascular safety with linagliptin in patients with type 2 diabetes mellitus: a pre-specified, prospective, and adjudicated meta-analysis of a Phase 3 programme. Cardiovasc Diabetol. 2012;11:3.
107. Kawamori R, Inagaki N, Araki E, et al. Linagliptin monotherapy provides superior glycaemic control versus placebo or voglibose with comparable safety in Japanese patients with type 2 diabetes: a randomized, placebo and active comparator-controlled, double-blind study. Diabetes Obes Metab. 2012;14(4):348-357.

108. Buse JB, Bergenstal RM, Glass LC, et al. Use of twice-daily exenatide in basal insulin-treated patients with type 2 diabetes: a randomized, controlled trial. Ann Intern Med. 2011;154(2):103-112.

109. Hamdy O, Carver C. The why WAIT program: improving clinical outcomes through weight management in type 2 diabetes. Curr Diab Rep. 2008;8:413-420.

110. Stenlöf K, Cefalu WT, Kim KA, et al. Efficacy and safety of canagliflozin monotherapy in subjects with type 2 diabetes mellitus inadequately controlled with diet and exercise. Diabetes Obes Metab. 2013;15(4):372-382.

111. Schernthaner G, Gross JL, Rosenstock J, et al. Canagliflozin compared with sitagliptin for patients with type 2 diabetes who do not have adequate glycemic control with metformin plus sulfonylurea: a 52-week randomized trial. Diabetes Care. 2013;36(9):2508-2515.

112. Bolinder J, Ljunggren Ö, Johansson L, et al. Dapagliflozin maintains glycaemic control while reducing weight and body fat mass over 2 years in patients with type 2 diabetes mellitus inadequately controlled on metformin. Diabetes Obes Metab. 2014;16(2):159-169.

113. Sjöström CD, Hashemi M, Sugg J, Ptaszynska A, Johnsson E. Dapagliflozin-induced weight loss impacts 24 week HbA1c and blood pressure levels. Diabetologia. 2013;56:S81.

114. Kohan DE, Fioretto P, Tang W, List JF. Long-term study of patients with type 2 diabetes and moderate renal impairment shows that dapagliflozin reduces weight and blood pressure but does not improve glycemic control. Kidney Int. 2014;85:962-971.

115. Pieber TR, Famulla S, Eilbracht J, et al. Empagliflozin as adjunct to insulin in patients with type 1 diabetes: a 4-week, randomized, placebo-controlled trial (EASE-1). Diabetes Obes Metab. 2015;17(10):928-935.

116. Rosenstock J, Jelaska A, Zeller C, et al. Impact of empagliflozin added on to basal insulin in type 2 diabetes inadequately controlled on basal insulin: a 78-week randomized, double-blind, placebo-controlled trial. Diabetes Obes Metab. 2015;17(10):936-948.

117. Rosenstock J, Seman LJ, Jelaska A, et al. Efficacy and safety of empagliflozin, a sodium glucose cotransporter 2 (SGLT2) inhibitor, as add-on to metformin in type 2 diabetes with mild hyperglycaemia. Diabetes Obes Metab. 2013;15(12):1154-1160.

118. Montañana $\mathrm{CF}$, Herrero $\mathrm{CH}$, Fernández MR. Less weight gain and hypoglycaemia with once-daily insulin detemir than NPH insulin in intensification of insulin therapy in overweight type 2 diabetes patients - the PREDICTIVE ${ }^{\mathrm{TM}}$ BMI clinical trial. Diabet Med. 2008;25:916-923.

119. Tyson CC, Appel LJ, Vollmer WM, et al. Impact of 5-year weight change on blood pressure: results from the Weight Loss Maintenance trial. J Clin Hypertens. 2013;15(7):458-464.

120. Canada H, Canada H. Guidelines for management of hypertension. Hypertens Canada. 2017;2.

121. Swartz SL. Endocrine and vascular responses in hypertensive patients to long-term treatment with diltiazem. J Cardiovasc Pharmacol. 1987;9:391-395.

122. Bergström J, Hultman E. The effect of thiazides, chlorthalidone and furosemide on muscle electrolytes and muscle glycogen in normal subjects. Acta Med Scand. 2009;180:363-376.

123. Finnerty FA, Maxwell MH, Lunn J, Moser M. Long-term effects of furosemide and hydrochlorothiazide in patients with essential hypertension: a two-year comparison of efficacy and safety. Angiology. 1977;28:125-133.

124. Reisin E, Weir MR, Falkner B, Hutchinson HG, Anzalone DA, Tuck ML. Lisinopril versus hydrochlorothiazide in obese hypertensive patients: a multicenter placebo-controlled trial. Hypertension. 1997;30(1):140-145.

125. Langford HG, Davis BR, Blaufox D, et al. Effect of drug and diet treatment of mild hypertension on diastolic blood pressure. The TAIM Research Group. Hypertension. 1991;17(2):210-217. 
126. Cirillo M, Marcarelli F, Mele AA, Romano M, Lombardi C, Bilancio G. Parallel-group 8-week study on chlorthalidone effects in hypertensives with low kidney function. Hypertension. 2014;63(4):692-697.

127. Leenen FHH, Smith DL, Boer WH, Marquez-Julio A. Diuretic and cardiovascular effects of indapamide in hypertensive subjects: a doseresponse curve. Curr Med Res Opin. 1983;8 Suppl 3:47-52.

128. Acchiardo SR, Skoutakis VA. Clinical efficacy, safety, and pharmacokinetics of indapamide in renal impairment. Am Heart J. 1983;106(1 Pt 2):237-244.

129. Isaac R, Witchitz S, Kamoun A, Bagattini JC. A long-term study of the influence of indapamide on the exchangeable potassium and sodium pools in hypertensive patients. Curr Med Res Opin. 1977;5:64-70.

130. Cotter G, Weissgarten J, Metzkor E, et al. Increased toxicity of high-dose furosemide versus low-dose dopamine in the treatment of refractory congestive heart failure. Clin Pharmacol Ther. 1997;62(2):187-193.

131. Al-Thanoon ZA, Mahmood IH. Effects of losartan vs. enalapril on the markers of metabolic syndrome. Oman Med J. 2012;27(1):27-30.

132. Apperloo Aj, de Zeeuw D, Sluiter HE, de Jong PE. Differential effects of enalapril and atenolol on proteinuria and renal haemodynamics in non-diabetic renal disease. BMJ. 1991;303:821-824.

133. Franciosa JA, Wilen MM, Jordan RA. Effects of enalapril, a new angiotensin-converting enzyme inhibitor, in a controlled trial in heart failure. J Am Coll Cardiol. 1985;5:101-107.

134. Koz C, Baysan O, Yokusoglu M, et al. The effects of perindopril on aortic elasticity and inflammatory markers in hypertensive patients. Med Sci Monit. 2009;15(7):Pi41-Pi45.

135. Jandrain B, Herbaut C, Depoorter JC, Voorde KV. Long-term (1 year) acceptability of perindopril in type II diabetic patients with hypertension. Am J Med. 1992;92(4B):S91-S94.

136. Ivanov K, Mychka V, Prokhorova J, et al. The effectiveness of therapy perindopril arginine in treatment of patients with hypertension and diabetes type 2 in national program "PREMIA". J Hypertens. 2011;29:e236.

137. Anichkov DA, Shostak NA, Schastnaya OV. Comparison of rilmenidine and lisinopril on ambulatory blood pressure and plasma lipid and glucose levels in hypertensive women with metabolic syndrome. Curr Med Res Opin. 2005;21(1):113-119.

138. Heeg JE, de Jong PE, van der Hem GK, de Zeeuw D. Efficacy and variability of the antiproteinuric effect of ACE inhibition by lisinopril. Kidney Int. 1989;36:272-279.

139. Yusuf S, Gerstein H, Hoogwerf B, et al. Ramipril and the development of diabetes. JAMA. 2001;286(15):1882-1885.

140. Farmer JA. Effect of ramipril on the incidence of diabetes (DREAM Study). Curr Atheroscler Rep. 2007;9(2):95.

141. Predel HG, Dusing R, Backer A, Kipnowski J, Kramer HJ. Combined treatment of severe essential hypertension with the new angiotensin converting enzyme inhibitor ramipril. Am J Cardiol. 1987;59:143D-148D.

142. Sharma AM, Pischon T, Hardt S, Kunz I, Luft FC. Adrenergic receptor blockers and weight gain: a systematic analysis. Hypertension. 2001;37:250-254.

143. Bauduceau B; UK Prospective Diabetes Study Group. Efficacy of atenolol and captopril in reducing risk of macrovascular and microvascular complications in type 2 diabetes: UKPDS 39. BMJ. 1998;317(713).

144. Houston MC, Olafsson L, Burger MC. Effects of nifedipine GITS and atenolol monotherapy on serum lipids, blood pressure, heart rate, and weight in mild to moderate hypertension. Angiology. 1991;42:681-690.

145. Davis BR. Effect of antihypertensive therapy on weight loss. Hypertension. 1992;19:393-399.

146. Richardson DW, Freund J, Gear AS, Mauck HP, Preston LW. Effect of propranolol on elevated arterial blood pressure. Circulation. 1968;37(4):534-542.

147. Rössner S, Taylor CL, Byington RP, Furberg CD. Long term propranolol treatment and changes in body weight after myocardial infarction. BMJ. 1990;300:902-903.
148. Macmahon SW, Bernstein L, Macdonald GJ, Andrews G, Blacket RB Comparison of weight reduction with metoprolol in treatment of hypertension in young overweight patients. Lancet. 1985;325:1233-1236.

149. Messerli FH, Bell DS, Fonseca V, et al. Body weight changes with betablocker use: results from GEMINI. Am JMed. 2007;120(7):610-615.

150. Freedman SF, Freedman NJ, Shields MB, et al. Effects of ocular carteolol and timolol on plasma high-density lipoprotein cholesterol level. Am J Ophthalmol. 1993;116(5):600-611.

151. Leren P, Foss PO, Nordvik B, Fossbakk B. The effect of enalapril and timolol on blood lipids: a randomized multicenter hypertension study in general practice in Norway. Acta Med Scand. 1988;223:321-326.

152. Pedersen OL, Mikkelsen E. Individual factors influencing the response to a beta-adrenergic blocking agent given alone and in combination with a diuretic in arterial hypertension. Eur J Clin Pharmacol. 1979; 16:311-317.

153. Hansson L, Berglund G, Andersson O, Holm M. Controlled trial of acebutolol in hypertension. Eur J Clin Pharmacol. 1977;12:89-92.

154. Alhenc-Gelas F, Plouin PF, Ducrocq MB, Corvol P, Menard J. Comparison of the antihypertensive and hormonal effects of a cardioselective beta-blocker, acebutolol, and diuretics in essential hypertension. Am J Med. 1978;64:1005-1012.

155. Gottdiener JS, Reda DJ, Williams DW, Materson BJ, Cushman W, Anderson RJ. Effect of single-drug therapy on reduction of left atrial size in mild to moderate hypertension: comparison of six antihypertensive agents. Circulation. 1998;98(2):140-148.

156. Walker BR, Deitch MW, Schneider BE, Hare LE. Comparative antihypertensive effects of guanabenz and methyldopa. Clin Ther. $1981 ; 4: 275-284$

157. Sterndorff B, Johansen P. The antihypertensive effect of pinacidil versus prazosin in mild to moderate hypertensive patients seen in general practice. Acta Med Scand. 1988;224:329-336.

158. Pollare T, Lithell H, Selinus I, Berne C. Application of prazosin is associated with an increase of insulin sensitivity in obese patients with hypertension. Diabetologia. 1988;31:415-420.

159. Mori H, Okada Y, Arao T, Nishida K, Tanaka Y. Telmisartan at $80 \mathrm{mg} /$ day increases high-molecular-weight adiponectin levels and improves insulin resistance in diabetic patients. Adv Ther. 2012;29:635-644.

160. Makita S, Abiko A, Naganuma Y, Moriai Y, Nakamura M. Effects of telmisartan on adiponectin levels and body weight in hypertensive patients with glucose intolerance. Metabolism. 2008;57: 1473-1478.

161. de Luis DA, Conde R, Gonzalez Sagrado M, et al. Effects of olmesartan vs irbesartan on metabolic parameters and visfatin in hypertensive obese women. Eur Rev Med Pharmacol Sci. 2010;14(9):759-763.

162. de Luis DA, Conde R, González-Sagrado M, et al. Effects of telmisartan vs olmesartan on metabolic parameters, insulin resistance and adipocytokines in hypertensive obese patients. Nutr Hosp. 2010;25(2):275-279.

163. Houlihan CA, Allen TJ, Baxter AL, et al. A low-sodium diet potentiates the effects of losartan in type 2 diabetes. Diabetes Care. 2002;25(4):663-671.

164. Schneider AW, Kalk JF, Klein CP. Effect of losartan, an angiotensin II receptor antagonist, on portal pressure in cirrhosis. Hepatology. 1999;29:334-339.

165. Rizos CV, Milionis HJ, Kostapanos MS, et al. Effects of rosuvastatin combined with olmesartan, irbesartan, or telmisartan on indices of glucose metabolism in Greek adults with impaired fasting glucose, hypertension, and mixed hyperlipidemia: a 24-week, randomized, open-label, prospective study. Clin Ther. 2010;32(3):492-505.

166. Bramlage P, Pittrow D, Kirch W. The effect of irbesartan in reducing cardiovascular risk in hypertensive type 2 diabetic patients: an observational study in 16600 patients in primary care. Curr Med Res Opin. 2004;20:1625-1631.

167. van der Zijl NJ, Serné EH, Goossens GH, et al. Valsartan-induced improvement in insulin sensitivity is not paralleled by changes in microvascular function in individuals with impaired glucose metabolism. J Hypertens. 2011;29(10):1955-1962. 
168. van der Zijl NJ, Moors CC, Goossens GH, Hermans MM, Blaak EE, Diamant M. Valsartan improves \{beta\}-cell function and insulin sensitivity in subjects with impaired glucose metabolism: a randomized controlled trial. Diabetes Care. 2011;34(4):845-851.

169. Saisho Y, Komiya N, Hirose H. Effect of valsartan, an angiotensin II receptor blocker, on markers of oxidation and glycation in Japanese type 2 diabetic subjects: blood pressure-independent effect of valsartan. Diabetes Res Clin Pract. 2006;74:201-203.

170. Masajtis-Zagajewska A, Majer J, Nowicki M. Effect of moxonidine and amlodipine on serum YKL-40, plasma lipids and insulin sensitivity in insulin-resistant hypertensive patients - a randomized, crossover trial. Hypertens Res. 2010;33:348-353.

171. Lorimer AR, Smedsrud T, Walker P, Tyler HM. A comparison of amlodipine, verapamil and placebo in the treatment of mild to moderate hypertension. Amlodipine Study Group. J Hum Hypertens. 1989;3(3):191-196.

172. Chrysant SG, Chrysant C, Trus J, Hitchcock A. Antihypertensive effectiveness of amlodipine in combination with hydrochlorothiazide. Am J Hypertens. 1989;2:537-541.

173. Sunderrajan S, Reams G, Bauer JH. Renal effects of diltiazem in primary hypertension. Hypertension. 1986;8:238-242.

174. Sasaki J, Saeki Y, Kawasaki K, et al. A multicenter comparison of nicorandil and diltiazem on serum lipid, apolipoprotein, and lipoprotein levels in patients with ischemic heart disease. Cardiovasc Drugs Ther. 1992;6(5):471-474.

175. Vermeulen A, Wester A, Willemse PFA, Lustermans FAT, Stegeman $\mathrm{CJ}$, de Bruijn JHB. Comparison of isradipine and diltiazem in the treatment of essential hypertension. Am J Med. 1988;84(3):42-45.

176. Takenaka T, Okayama M, Kojima E, et al. Aliskiren reduces morning blood pressure in hypertensive patients with diabetic nephropathy on hemodialysis. Clin Exp Hypertens. 2013;35(4):244-249.

177. Siddiqi L, Oey PL, Blankestijn PJ. Aliskiren reduces sympathetic nerve activity and blood pressure in chronic kidney disease patients. Nephrol Dial Transplant. 2011;26(9):2930-2934.

178. Jordan J, Engeli S, Boye SW, Le Breton S, Keefe DL. Direct renin inhibition with aliskiren in obese patients with arterial hypertension. Hypertension. 2007;49:1047-1055.

179. Berthon BS, Macdonald-Wicks LK, Wood LG. A systematic review of the effect of oral glucocorticoids on energy intake, appetite, and body weight in humans. Nutr Res. 2014;34(3):179-190.

180. Berthon BS, Gibson PG, Mcelduff P, Macdonald-Wicks LK, Wood LG. Effects of short-term oral corticosteroid intake on dietary intake, body weight and body composition in adults with asthma - a randomized controlled trial. Clin Exp Allergy. 2015;45:908-919.

181. Brown ES, Chandler PA. Mood and cognitive changes during systemic corticosteroid therapy. Prim Care Companion J Clin Psychiatry. 2001;3:17-21.

182. Wung PK, Anderson T, Fontaine KR, et al. Effects of glucocorticoids on weight change during the treatment of Wegener's granulomatosis. Arthritis Rheum. 2008;59(5):746-753.
183. Dessein PH, Joffe BI, Stanwix AE, Christian BF, Veller M. Glucocorticoids and insulin sensitivity in rheumatoid arthritis. $J$ Rheumatol. 2004;31(5):867-874.

184. Stenson WF, Cort D, Rodgers J, et al. Dietary supplementation with fish oil in ulcerative colitis. Ann Intern Med. 1992;116(8):609-614.

185. Hjelmesaeth J, Hartmann A, Kofstad J, et al. Glucose intolerance after renal transplantation depends upon prednisolone dose and recipient age. Transplantation. 1997;64(7):979-983.

186. Gorard DA, Hunt JB, Payne-James JJ, et al. Initial response and subsequent course of Crohn's disease treated with elemental diet or prednisolone. Gut. 1993;34(9):1198-1202.

187. Mckenzie R, O'Fallon A, Dale J, et al. Low-dose hydrocortisone for treatment of chronic fatigue syndrome: a randomized controlled trial. JAMA. 1998;280(12):1061-1066.

188. Sheehan HL, Summers VK. Oral cortisone treatment of hypopituitarism. Br Med J. 1954;1(4864):723-726.

189. Chrousos GA, Kattah JC, Beck RW, Cleary PA. Side effects of glucocorticoid treatment. Experience of the Optic Neuritis Treatment Trial. JAMA. 1993;269(16):2110-2112.

190. Cheskin LJ, Bartlett SJ, Zayas R, Twilley CH, Allison DB, Contoreggi C. Prescription medications: a modifiable contributor to obesity. South Med J. 1999;92(9):898-904.

191. Alvarez-Jiménez M, Hetrick SE, González-Blanch C, Gleeson JF, Mcgorry PD. Non-pharmacological management of antipsychotic-induced weight gain: systematic review and meta-analysis of randomised controlled trials. Br J Psychiatry. 2008;193:101-107.

192. Imayama I, Alfano CM, Mason C, et al. Weight and metabolic effects of dietary weight loss and exercise interventions in postmenopausal antidepressant medication users and non-users: a randomized controlled trial. Prev Med. 2013;57(5):525-532.

193. Drent ML, van der Veen EA. Lipase inhibition: a novel concept in the treatment of obesity. Int J Obes Relat Metab Disord. 1993;17(4): 241-244.

194. Novo Nordisk. Saxenda Product Monograph. (2016). Available from: http://www.novonordisk.ca/content/dam/Canada/AFFILIATE/ www-novonordisk-ca/OurProducts/PDF/Saxenda_PM_English.pdf. Accessed April January 20, 2017.

195. Greenway FL, Plodkowski RA, Greenway FL. Effect of naltrexone plus bupropion on weight loss in overweight and obese adults (COR-I): a multicentre, randomised, double-blind, placebo-controlled, Phase 3 trial. Lancet. 2010;376:595-605.

196. Douketis JD, Macie C, Thabane L, Williamson DF. Systematic review of long-term weight loss studies in obese adults: clinical significance and applicability to clinical practice. Int J Obes. 2005;29:1153-1167.

197. Kinon BJ, Basson BR, Gilmore JA, Tollefson GD. Long-term olanzapine treatment: weight change and weight-related health factors in schizophrenia. J Clin Psychiatry. 2001;62:92-100.

198. Henderson DC, Cagliero E, Gray C, et al. Clozapine, diabetes mellitus, weight gain, and lipid abnormalities: a five-year naturalistic study. Am J Psychiatry. 2000;157(6):975-981.

Diabetes, Metabolic Syndrome and Obesity: Targets and Therapy

Dovepress

\section{Publish your work in this journal}

Diabetes, Metabolic Syndrome and Obesity: Targets and Therapy is an international, peer-reviewed open-access journal committed to the rapid publication of the latest laboratory and clinical findings in the fields of diabetes, metabolic syndrome and obesity research. Original research, review, case reports, hypothesis formation, expert opinion and commentaries are all considered for publication. The manuscript management system is completely online and includes a very quick and fair peer-review system, which is all easy to use. Visit http://www.dovepress.com/testimonials.php to read real quotes from published authors. 